\title{
5
}

\section{CONFIABILIDADE, COERÊNCIA E METAINCOERÊNCIA}

\section{RELIABILITY, COHERENCE AND METAINCOHERENCE}

\author{
Emerson Carlos Valcarenghi*
}

\begin{abstract}
RESUMO - Este artigo discute casos de metaincoerência doxástica em que a crença metaincoerente é ativa na geração da crença-alvo. Esses casos, que são casos de injustificação doxástica, provam a necessidade de complementarmos as propostas confiabilistas de justificação. É essa complementação que tentaremos fazer aqui, mas sem recorrer a qualquer cláusula do tipo "antisolapamento da justificação".

PALAVRAS-CHAVE - Justificação doxástica. Confiabilismo. Metaincoerência.

ABSTRACT - This essay discusses cases of doxastic metaincoherence in which the metaincoherent belief is active in target-belief generation. These cases, which are cases of doxastic non-justification, show the need to complement reliabilist proposals of justification. This is what we try to do here, but not recurring to any clause of the kind "undermining of justification".
\end{abstract}

KEYWORDS - Doxastic justification. Reliabilism. Metaincoherence.

Em ensaio anterior ${ }^{1}$, mostramos que, se uma crença metaincoerente não é ativa na geração da crença-alvo, ela também não é relevante para a justificação/injustificação dessa crença. Consequência disso é que a concepção confiabilista de justificação doxástica não tem de incorporar uma cláusula do tipo antisolapamento da justificação, tal como Goldman o propôs ${ }^{2}$. Naquele mesmo ensaio, deixamos duas perguntas

* Professor do Mestrado emÉtica e Epistemologia da UFPI. <ecvalcarenghi@yahoo.com.br>.

1 Cf. o meu Confiabilismo e Metaincoerência.

2 Cf. What Is Justified Belief?, Epistemology and Cognition, Strong and Weak Justification e Reliabilism.

\begin{tabular}{|l|l|l|l|l|l|}
\hline Veritas & Porto Alegre & v. 55 & n. 2 & maio/ago. 2010 & p. $60-87$ \\
\hline
\end{tabular}


não-respondidas, as quais poderiam ser reduzidas à seguinte: crenças metaincoerentes ativas na geração da crença-alvo são, ou não, relevantes à justificação dessa crença? Para respondê-la com correção, teremos de fazer uma série de considerações preliminares. A primeira delas é a de que, embora tenhamos argumentado contra a incorporação de uma cláusula do tipo antisolapamento à cláusula da confiabilidade, isso não nos torna reféns da tese de que justificação doxástica se limita à confiabilidade do procedimento gerador da crença ${ }^{3}$. Muito pelo contrário, queremos sustentar que o conceito de confiabilidade é insuficiente para efetuar aquela análise e pensamos que os casos a seguir podem mostrá-lo:

3 Temos defendido a tese de que, se um procedimento é confiável na geração de crenças, então ele produz mais crenças verdadeiras do que falsas, considerando o histórico total de suas ocorrências geradoras no mundo específico em que ocorre. Considerar a histórico total de ocorrências de um procedimento, no mundo em que ele ocorre, significa considerar o conjunto completo de ocorrências passadas, presentes e futuras desse procedimento naquele mundo. Desse modo, a confiabilidade de um procedimento de geração de crença é, em razão da meta do agente de obter mais crenças verdadeiras do que falsas, algo que depende da proporção entre crenças verdadeiras às crençase crenças falsas geradas pelo procedimento desde o gênesis até o apocalipse do mundo em que tal procedimento ocorre. Tal concepção de confiabilismo não é exatamente a mesma que Goldman defende. Aliás, a explicação de Goldman para esse conceito tem recebido considerável complementação e/ou retificação ao longo dos textos. Goldman começou afirmando que um processo confiável é aquele que produz, a longo prazo e no nosso mundo (mundo que Goldman toma como sendo o real), mais crenças verdadeiras do que crenças falsas (cf. What is Justified Belief?, p. 179-182). Goldman afirmou também que a confiabilidade de um processo tem de ser entendida, não apenas em termos da sua ocorrência real, mas em termos da sua propensão para ser confiável, ou seja, em termos da sua confiabilidade subjuntiva. Desse modo, para que um processo seja confiável, ele tem de ser capaz de produzir mais crenças verdadeiras do que crenças falsas em outro(s) mundo(s) (cf. What is Justified Belief?, p. 180). In: Epistemology and Cognition, p. 103-109, Goldman revê a sua posição inicial de que a confiabilidade teria de ser definida nos termos de uma associação nosso mundo-mundo real e passa a defini-la nos termos de uma associação nosso mundo-mundo normal (p. 107-109). Mantendo a ideia da necessidade da confiabilidade subjuntiva, Goldman passou a defender posteriormente a ideia de que confiabilidade deve ser definida na relação com o mundo em que o processo ocorre, independentemente de se esse mundo é o nosso, o real ou o mundo normal (cf. Strong and Weak Justification, p. 62-63). Ainda a propósito das dificuldades enfrentadas na análise do conceito de confiabilidade, gostaríamos de registrar outra. Conforme já dissemos acima, a confiabilidade de um procedimento de geração doxástica depende de sua performance, dada a história completa de geração doxástica desse procedimento no mundo em que ocorre. Mas, sendo assim, concedemos que são cabíveis as seguintes perguntas: supondo que a crença-P de $\mathrm{S}$ seja gerada pelo procedimento- $\pi$, que confiabilidade seria necessária para a justificação dessa crença? A confiabilidade de $\pi$ considerando a sua performance em relação a todos os agentes que o executam ou a confiabilidade de $\pi$ considerando a sua performance apenas em relação à execução por parte de S? 
Caso-1: Suponhamos, em relação ao mundo em que S habita, que seja verdadeira a teoria que postula que, quanto maior a quantidade de matéria de um objeto, mais intensamente ele será atraído para o centro do planeta. Suponhamos que S não tenha qualquer opinião a respeito desse assunto. Mesmo assim, $\mathrm{S}$ forma a crença de que toda melancia que ele soltar de suas mãos cairá. Suponhamos que S tenha inferido tal crença de outra crença sua: a crença justificada de que a melancia de que ele mais gostava se esborrachou no chão, após tê-la deixado cair de suas mãos. Para encerrar o nosso caso, suporemos que os procedimentos executados por S na cadeia de geração de sua crença-alvo formam apenas o tipo de crença que geraram;

Caso-2: Suponhamos que a teoria da atração gravitacional e a teoria da evolução das espécies biológicas expressem princípios naturais do mundo em que $\mathrm{S}$ habita. Vamos também supor que $\mathrm{S}$ acredita justificadamente na teoria da atração gravitacional, tendo formado tal crença através de um procedimento que gera apenas o tipo de crença em questão. Imaginemos agora que, exclusivamente a partir de sua crença na teoria da atração gravitacional, S infere a sua crença na teoria da evolução das espécies biológicas. Assim como no caso anterior, suporemos que o procedimento executado por $\mathrm{S}$ para gerar sua crença-alvo forma sempre o mesmo tipo de crença.

De que modo reagimos diante dos casos acima? SDito de forma simplesmente, atribuímos injustificação às respectivas crenças-alvo. E nós o fazemos a despeito do fato de os procedimentos de geração daquelas crenças serem confiáveis ${ }^{4}$. Assim, só podemos concluir que crença justificada não é apenas crença gerada por procedimento confiável. Mas, se é assim, que conceito(s) falta(m) para que completemos a análise do conceito em jogo? Para respondermos a essa pergunta, dispomos de, pelo menos, duas estratégias. A primeira seria arriscar

4 Embora os casos em jogo não informem explicitamente, a satisfação da exigência de confiabilidade não-condicional também estaria garantida em relação àqueles casos. Isso em razão de que, quaisquer que tenham sido os procedimentos não-inferenciais geradores das crenças-premissas daqueles casos, esses procedimentos seriam não-condicionalmente confiáveis, já que, segundo aqueles casos, aqueles procedimentos gerariam apenas aquele tipo específico de crença-premissa (cf. a noção de confiabilidade condicional de Goldman in: What is Justified Belief?). Importante: a expressão "crença-premissa" será aqui usada para nos referirmos à crença cuja proposição-objeto figura como premissa do argumento inscrito na inferência de um agente. Com as devidas adaptações, o mesmo uso será dado por nós aqui à expressão "crença-conclusão". 
uma resposta que testaríamos frente às nossas intuições conceituais. A segunda seria escolher alguma das propriedades que atribuímos aos procedimentos de geração de crença daqueles casos e, com isso, compor uma resposta que seria, então, submetida ao crivo das nossas intuições conceituais. Optaremos pela segunda estratégia. Nesse caso, começaremos constatando que a geração das crenças-alvo daqueles casos é inferencial. E aquela geração é de tipo inferencial, porque os procedimentos que geram àquelas crenças-alvo estabelecem relação com um item proposicional ${ }^{5}$. O Caso-1 é de inferência indutiva ${ }^{6}$. Já o

5 Mas, as crenças não são os únicos procedimentos do agente que têm relação com itens proposicionais. Suposições também fazem isso. E, nesse caso, parece-nos que as suposições também poderiam gerar crença justificada. Para vê-lo, vamos conceber que $\mathrm{S}$ suponha que $\mathrm{P}$. Imaginemos agora que tal suposição cause em $\mathrm{S}$ a crença de que $(\mathrm{P} \rightarrow \mathrm{P})$. Ora, parece-nos perfeitamente aceitável, por exemplo, que a crença de que $(\mathrm{P} \rightarrow \mathrm{P})$ poderia ser justificada por aquela suposição de $\mathrm{S}$. Mas, com esse caso, não estamos querendo sugerir que as suposições permitiriam gerar apenas crenças justificadas em proposições triviais. Imaginemos que S supusesse que $\mathrm{P}$ e deduzisse $\mathrm{Q}$ de $\mathrm{P}$. Isso posto, vamos supor que essa suposição e dedução de $\mathrm{S}$ cause em bloco a crença de $\mathrm{S}$ de que $(\mathrm{P} \rightarrow \mathrm{Q})$. Ora, parece-nos perfeitamente adequado dizer que essa crença poderia ser justificada por aquele bloco procedimental.

6 Harman e Kulkarni sugerem que a seguinte sequência expressa a forma-padrão da inferência indutiva: a partir de n-crenças de $\mathrm{S}$ de que ele percebera $\mathrm{n}$-corvos particulares negros e de sua crença de que não percebera nenhum corvo não-negro, S passa a crer que todos os corvos são negros (The Problem of Induction, p. 559). Parece-nos, porém, duvidoso que a sequência acima capture corretamente aquela forma. Ela nos parece exigente demais. Afinal de contas, ela não apenas estabelece que $\mathrm{S}$ tenha crença sobre as suas próprias percepções, mas estabelece que $\mathrm{S}$ tenha também a crença de que não percebera nenhum corvo não-negro. Se, de fato, S não percebera nenhum corvo não-negro, embora tivesse percebido n-corvos particulares negros, por que afinal ele teria de crer que não percebera nenhum corvo não-negro para crer que todos eles são negros? Por outro lado, a forma sugerida por Harman e Kulkarni nos parece muito concessiva. Ela não exige, por exemplo, que S reúna todo o conteúdo proposicional correspondente às propriedades dos n-corvos particulares em uma só crença de partida. O padrão proposto pelos autores mencionados permite que $\mathrm{S}$ infira a crença de que todos os corvos são negros a partir de n-crenças acerca de n-corvos particulares em vez de fazê-lo a partir de uma crença única de S na conjunção de que: c é um corvo e é negro, $\mathrm{c}_{1}$ é um corvo e é negro... $\mathrm{C}_{\mathrm{n}}$ é um corvo e é negro. Acreditamos que, para $\mathrm{S}$ estar justificado em uma crença formada através de uma inferência indutiva, o procedimento de geração da crença-alvo teria de recuperar e unificar de modo indivisível os conteúdos proposicionais que são objeto das n-crenças de partida para, só então, S poder inferir a crença-alvo. A nossa suspeita é de que a sequência que melhor expressa a forma standard de uma inferência indutiva seja a seguinte: a partir da crença de $\mathrm{S}$ de que $\mathrm{n}$-corvos particulares são negros, $\mathrm{S}$ forma a crença de que todos os corvos são negros (onde " $n$ " representa um número indutivamente adequado em relação ao tipo de situação em jogo e a crença de partida de S, isto é, a crença de que n-corvos particulares são negros, tenha sido causada pela memória de $\mathrm{S}$ que é relativa às atribuições feitas por ele em situações perceptuais. Ao recuperar um determinado conteúdo de sua memória, S pode atribuir a esse conteúdo recuperado todos aqueles conceitos que ele atribuiu quando executou o procedimento perceptual gerador do conteúdo mnemônico em questão). 
Caso-2 não é de inferência indutiva, nem dedutiva. O mais importante, porém, é que são defeituosas ambas as inferências do agente daqueles casos. E aquelas inferências são defeituosas porque os argumentos nelas inscritos não contemplam nenhuma forma dedutiva de argumento e nenhuma forma indutiva válida de argumento ${ }^{7}$. Para sermos mais específicos, a forma do argumento inscrito na inferência do Caso-1 é indutivamente inválida e tem sido, tradicionalmente, chamada de "generalização precipitada". O seu defeito reside na insuficiência do número de indivíduos que constitui a amostra a partir da qual $\mathrm{S}$ projetaria a propriedade em jogo no argumento. Mais especificamente, a crença-premissa do agente do Caso-1 veicula um número insuficiente de melancias cadentes para que ele possa projetar validamente o conceito de queda universal das melancias em sua crença-conclusão. Quanto à forma da inferência realizada por S no Caso-2, ela não é, em nenhum sentido, adequada, afinal, o argumento inscrito naquela inferência não é nem dedutivao e não é indutivamente válido.

Ora, se considerarmos, então, que a mera confiabilidade dos procedimentos inferenciais que os agentes dos casos acima usaram para gerar as suas crenças-alvo não é suficiente para fazer com que eles se fazer com quetornem sejam procedimentos justificadores doxásticos, levando também em conta; as propriedades daquelas inferências,

7 Pensamos que podemos falar sem metáforas, ou ambiguidades, na validade/invalidade de formas indutivas de inferência e que, ao fazê-lo, não estaremos nos comprometendo com a ideia de que uma "lógica indutiva" seria possível. Concordamos com a perspectiva adotada por Harman e Kulkarni (op. cit., p. 561-564) de que a visão tradicional da indução está às voltas com um erro categorial, ao colocar dedução e indução na mesma categoria. Segundo esses autores, a visão tradicional “(...) confunde duas coisas muito diferentes, a teoria do raciocínio e a teoria daquilo-que-se-segue-de. A lógica, ou as lógicas, são uma teoria daquilo-que-se-segue-de, não uma teoria da inferência ou do raciocínio" (op. cit., p. 561). Concordamos com os autores mencionados e, apesar das aparências em contrário, parece-nos que podemos falar da validade/invalidade de formas indutivas de inferência sem caracterizar compromisso com a tese de que há uma lógica indutiva. A propósito disso, os próprios Harman e Kulkarni, por exemplo, falam de sua pretensão em desenvolver modelos formais de inferência indutiva (op. cit., p. 564). Ora, se podemos desenvolver modelos formais de inferência indutiva, então por que não poderíamos falar, sem metáforas ou ambiguidades, na validade/invalidade dos argumentos que se encontram inscritos nesses modelos? Parece-nos que poderíamos. O que teríamos de evitar, nesse caso, seria o erro de tomar dedutibilidade como o único critério da validade de um argumento. Esse, inclusive, teria sido um dos erros cometidos por Hume (cf. Investigações sobre o entendimento humano) e Popper (cf. Conhecimento objetivo e Logic of Scientific Discovery) em seus tratamentos da inferência indutiva e da capacidade, ou não, desse tipo de inferência justificar uma crença, haja vista a resolução cética que tais autores deram ao chamado "problema da indução". Sendo assim, podemos dizer que o erro categorial do qual Harman e Kulkarni acusam a tradição pode ser explicado justamente pelo erro do qual acusamos Hume e Popper, isto é, considerar que a dedutibilidade é o único critério de validade de um argumento. 
gostaríamos de oferecer a seguinte proposta inicial de análise para o conceito de justificação doxástica inferencial:
$\left(\mathrm{JDI}_{\text {inicial }}\right): \quad$ Se a crença-P de S está inferencialmente justificada, então: (1) o procedimento inferencial executado por S para crer que $P$ é confiável; (2) o procedimento inferencial que gera a crença-P e a crença-P expressam uma forma adequada de infe- rência ${ }^{8}$.

Mas, apesar de $\left(\mathrm{JDI}_{\text {inicial }}\right)$ ser verdadeira, essa proposta ainda é insuficiente para capturar completamente o conjunto de conceitos que usamos ao atribuir justificação doxástica em casos inferenciais. Para vê-lo, consideremos os seguintes:

8 Algumas observações a respeito da cláusula (2) de ( $\left.\mathrm{JDI}_{\text {inicial }}\right)$. Em primeiro lugar, essa cláusula, que é parte de nossa estratégia geral de tratamento dos casos de metaincoerência ativa, não tem o caráter anulabilista da cláusula antisolapamento proposta por Goldman para lidar com tais casos, como ele mesmo o assume in: Reliabilism (para uma crítica anulabilista ao anulabilismo da cláusula antisolapamento de Goldman, cf. Kvanvig in: Two Approaches to Epistemic Defeat). A segunda observação a respeito da cláusula (2) de ( $\left.\mathrm{JDI}_{\text {inicial }}\right)$ é a de que ela encontra alguma consonância com a exigência de Armstrong de que uma inferência esteja de acordo com um bom princípio (cf. A Materialist Theory of Mind, p. 200-204). A terceira, e talvez a mais importante observação que faremos aqui sobre a cláusula em jogo, está relacionada ao seguinte caso: suponhamos que $\mathrm{Q}$ seja uma proposição contingente e $\mathrm{P}$ uma verdade necessária. Suponhamos agora que $\mathrm{S}$ forma a crença de que $\mathrm{P}$ inferida a partir de sua crença de que Q. Ora, tal como podemos ver, o tipo de inferência em jogo não faria, sob nenhuma hipótese, com que S saísse de uma verdade para uma falsidade doxástica. Por essa razão, o argumento inscrito nessa inferência poderia ser tomado, inicialmente, como dedutivo. Ocorre que anteriormente afirmamos que as inferências cujo argumento inscrito é dedutivo ou válido indutivamente expressam uma forma adequada de inferência. Sendo assim, agora estamos diante de uma situação complicada, pois não diríamos que a inferência em jogo é correta. Se, motivado pela crença de que Roma é a capital da Itália, $\mathrm{S}$ formasse a crença de que chove ou não chove, não diríamos que essa inferência seria adequada, mesmo que, em relação à forma dessa inferência, seria impossível que $\mathrm{S}$ saísse de uma crença verdadeira e aportasse em uma crença falsa. Temos aqui duas opções: ou assumimos que a inferência feita por $\mathrm{S}$ não é realmente dedutiva (baseados, por exemplo, na ideia de que a impossibilidade de uma crença-conclusão ser falsa, dada a verdade da crença-premissa, constitui um atributo apenas necessário para que uma inferência seja dedutiva, embora não suficiente), ou o fato de uma inferência ser dedutiva não seria suficiente para que ela fosse adequada. Mas, alguém poderia sugerir uma terceira opção, ou seja, restringir o escopo da exigência expressa na cláusula (2) de (JDI inicial $)$ para que ela valesse apenas para a justificação de crenças em proposições contingentes. É evidente, porém, que essa saída, via restrição do escopo de análise, apenas postergaria a dificuldade agora enfrentada para a ocasião em que lidaríamos com o problema da justificação doxástica em proposições necessárias. Mas, a despeito da relevância que essa discussão venha a ter, não poderemos levá-la adiante, ao menos neste ensaio, pois, ironicamente, também temos uma limitação de escopo aqui. 
Caso-3: Suponhamos que um procedimento qualquer de geração de crença de $\mathrm{S}$ gere apenas, e tantas vezes quanto quisermos, a crença contraditória de que Q: chove em Porto Alegre e não chove em Porto Alegre 9 . Agora, suponhamos que, toda vez que $\mathrm{S}$ forma a crença-O, ele infere apenas a crença de que $\mathrm{P}$ : chove em Porto Alegre. Para terminar, suponhamos que o mundo em que $\mathrm{S}$ e Porto Alegre coexistem é o mesmo e, para a infelicidade de muitos, a capital de todos os gaúchos tem sido, é e será chuvosa.

Caso-4: Suponhamos que S queira tomar informações, ou tenha uma dúvida, a respeito de um determinado assunto. S procura dois amigos, $S_{1}$ e $S_{2}$, que acredita serem especialistas na matéria. $S$ faz a pergunta pertinente e ouve, quase que simultaneamente, a resposta de que $\mathrm{P}$ por parte de $\mathrm{S}_{1}$ e a resposta de que $\sim \mathrm{P}$ por parte de $\mathrm{S}_{2}$. A partir desse, e de outros procedimentos relevantes, $\mathrm{S}$ sempre forma a crença de que $\mathrm{Q}: \mathrm{S}_{1}$ e $\mathrm{S}_{2}$ são especialistas no assunto relativo à proposição-P e declararam verdades ao se manifestarem tal como se manifestaram a respeito dele ${ }^{10}$.

9 Outros tipos de crença inconsistente também poderiam ser usados para atingir os mesmos objetivos que pretendemos atingir com o emprego do caso acima. O uso da contradição direta se deu apenas em razão de sua maior simplicidade.

10 Algumas considerações em torno do Caso-4 talvez venham a ser úteis para evitar mal-entendidos. Primeiramente, para que o Caso-4 constitua um contraexemplo à tese da mera confiabilidade na análise da justificação inferencial, é necessário que $S$ gere a crença-alvo, seja ela $\mathrm{P}$, ou $\sim \mathrm{P}$, a partir de um procedimento que conjugue o conteúdo de ambas as declarações dos amigos especialistas. Do contrário, estaríamos discutindo apenas um caso de mudança de opinião (caso com o qual não lidaremos agora, mas que, consideradas algumas propriedades relevantes envolvidas no caso acima, talvez representasse até mesmo um ataque mais contundente contra aquela tese). Em segundo lugar, não devemos confundir a confiabilidade de $\mathrm{S}_{1}$ ou de $\mathrm{S}_{2}$, enquanto especialistas em um determinado assunto, com a confiabilidade do procedimento de geração de crença de S ligado ao fato dele testemunhar as manifestações daqueles especialistas. A confiabilidade de um indivíduo em declarar verdades sobre um determinado assunto não equivale à confiabilidade do procedimento de geração doxástica do agente que testemunha as manifestações de um especialista. Para vê-lo, suponha que $\mathrm{S}_{3}$ seja um especialista em meteorologia. Se $\mathrm{S}_{3}$ é um especialista no assunto, ele declara mais verdades do que falsidades sobre o tema. Contudo, assumiremos também que, embora $\mathrm{S}_{3}$ seja um confiável declarador de verdades sobre precipitação de chuva, ele não o seja em relação à precipitação de neve (é claro que, nesse caso, $\mathrm{S}_{3}$ contrabalança os seus fracassos em prognosticar precipitação de neve com mais acertos proporcionais em seus prognósticos de precipitação de chuva). Nesse caso, parece-nos claro que, embora $\mathrm{S}_{3}$ seja um confiável meteorologista, as suas afirmações sobre precipitação de neve podem tornar inconfiável o procedimento de geração doxástica do agente que forma uma crença, partindo, entre outros procedimentos, da audição de suas declarações sobre o assunto. Ou seja, mesmo que $\mathrm{S}_{3}$ seja um meteorologista confiável e que $\mathrm{S}$ forme a crença de que amanhã nevará inferindo-a da sua crença de que $\mathrm{S}_{3}$ é um. 
Suponhamos agora que, de sua crença de que $\mathrm{Q}, \mathrm{S}$ infere a crença de que $\mathrm{P}$. Por fim, imaginemos que, toda vez que $\mathrm{S}$ forma a crença- $Q$, ele infere apenas a crença de que $\mathrm{P}$, que consiste em uma verdade natural sobre o assunto.

Conforme podemos ver, os procedimentos inferenciais que geram as crenças-alvo dos casos acima são todos confiáveis. Além disso, não há qualquer invalidade na inferência das crenças-alvo pelos respectivos agentes. Apesar disso, atribuímos injustificação àquelas crenças. Desse modo, os casos acima provam que ( $\left.\mathrm{JDI}_{\text {inicial }}\right)$ não é suficiente para capturar os nossos usos do conceito de justificação inferencial do tipo crença-para-crença. A nossa suspeita é de que, para esses casos, (JDI inicial ) carece da tese, que chamaremos de "tese da dependência", a seguir:

(TD):

Se $\mathrm{S}$ infere a crença-P da crença- $\mathrm{Q}$ e a crença-P está justificada, então a crença-Q está justificada ${ }^{11}$.

confiável declarador de proposições meteorológicas e $\mathrm{S}_{3}$ declarou que amanhã vai nevar, o procedimento inferencial que gera a crença-alvo correspondente pode ser inconfiável. Isso porque $\mathrm{S}$ poderia ter a sorte de ouvir apenas as manifestações verdadeiras do inconfiável declarador de proposições sobre precipitação de neve (o que colocaria esse caso no rol dos casos de tipo-Gettier) ou, em uma situação oposta, S poderia ter o azar de ouvir apenas as manifestações falsas do confiável declarador de proposições sobre precipitação de chuva. Ou seja, a confiabilidade de um indivíduo em relação a um determinado assunto não necessariamente torna confiável o procedimento gerador da crença-alvo daquele agente que testemunha as manifestações correspondentes. Por último, queremos assumir, sem muitas explicações por enquanto, que, para que $\mathrm{S}$ esteja testemunhalmente justificado em uma determinada crença, é necessário que ele a infira de uma crença cujo conteúdo mínimo contenha a proposição de que o indivíduo, de quem $\mathrm{S}$ testemunha a manifestação proposicional, declarou isso e aquilo sobre um determinado assunto a respeito do qual ele é um confiável declarador de verdades. Se essa exigência soa desconfortável, queremos observar, muito rapidamente, o quão contraintuitivo seria alegar que S está justificado na crença de que P somente porque ouviu alguém dizer "P" e o quão contraintuitivo seria dizer que S está justificado na crença de que $\mathrm{P}$, se $\mathrm{S}$ acredita que o declarante é alguém no qual ele crê ser inconfiável acerca do respectivo assunto (para esclarecimentos adicionais a respeito desse ponto, ver a discussão do Caso-9).

11 Goldman faz uma exigência semelhante a (TD), através da cláusula $\left(6_{\mathrm{B}}\right)$ de What is Justified Belief?, p. 183. Fato curioso é que Goldman parece não repeti-la in: Epistemology and Cognition. A diferença entre (TD) e a exigência feita na cláusula $\left(6_{\mathrm{B}}\right)$ de Goldman é a de que, enquanto a primeira exige apenas que a crença-premissa tenha sido gerada por um processo confiável, (TD) exige que ela seja uma crença justificada. Segundo Dancy, (TD) faz parte do núcleo-duro do argumento cético-pirrônico do regresso ao infinito da justificação (cf. Epistemologia Contemporânea, p. 76). Essa sugestão nos parece correta. Afinal de contas, não há como argumentar em favor da necessidade de um exercício ad infinitum da oferta de razões pelo agente, se (TD), ou algo equivalente, não constar entre as teses do respectivo argumento cético. De qualquer modo, a aceitação de (TD) não torna ninguém comprometido com as demais teses que compõe o argumento pirrônico. Tal observação, aliás, oportuniza uma breve observação acerca da relação entre (TD) 
Em outras palavras, (TD) exige que a crença-premissa de uma inferência esteja justificada para que a crença-conclusão o esteja. Nesse caso, podemos concluir que nenhuma crença pode constituir, em sentido estrito, um justificador doxástico. E, se uma crença pode estar inferencialmente justificada, mas não pode ser um justificador doxástico, então a crença-premissa de uma inferência do agente constitui apenas uma espécie de transferidor da justificação/injustificação para a respectiva crença-conclusão daquela inferência. Sendo assim, vamos oferecer, a seguir, uma proposta de análise para o conceito de justificação doxástica inferencial do tipo crença-para-crença - ou, para fixarmos algum padrão terminológico aqui, para o conceito de justificação doxástica doxasticamente inferencial:

$\left(\mathrm{JDDI}_{\text {inicial }}\right)$ : Se a crença-P de S está doxástico-inferencialmente justificada, então: (1) S infere a crença-P da crença-Q; (2) o procedimento inferencial executado por S é confiável; (3) o procedimento inferencial que gera a crença-P e a crença-P expressam uma forma adequada de inferência; (4) a crença-Q de S está justificada.

$\left(\mathrm{JDDI}_{\text {inicial }}\right)$ é, tal como vimos, a nossa proposta inicial para uma análise parcial do conceito de justificação doxástica doxasticamente inferencial. Sendo assim, precisamos agora reformular a terminologia, mas principalmente adaptar o conteúdo de outra proposta que aqui já lançamos, ou seja, $\left(\mathrm{JDI}_{\text {inicial }}\right)$. Apenas para lembrar, ela foi usada para expressar a nossa proposta inicial de análise parcial da justificação inferencial, porém, sem uma especificação de se ela seria, para a justificação, doxasticamente inferencial ou não-doxasticamente inferencial. Agora que temos uma proposta específica para a justificação doxástica doxasticamente

e a proposta infinitista de justificação defendida por Klein. Esse autor sustenta que a justificação de uma proposição-alvo aumenta à medida que o agente oferece razões e que o número de razões disponíveis para o agente é potencialmente infinito (cf. Is Infinitism the Solution to the Regress Problem?, p. 141-140). O ponto é que, se as teses de Klein são verdadeiras, (TD) é falsa. Afinal, (TD) não é compatível com a ideia de que a justificação aumenta à medida que o agente oferece razões, razões para as razões iniciais e razões para as razões para as razões iniciais, etc. De acordo com (TD), a justificação inferencial tem uma natureza puramente condicional (Dancy também assume que ela possui essa natureza in: Epistemologia Contemporânea, p. 76). Ora, se a justificação inferencial tem uma natureza puramente condicional, então não importa o tamanho da cadeia de razões oferecidas pelo agente, pois a crença-premissa de cada inferência da cadeia terá de estar justificada - não meio-justificada ou quase-justificada -, para que a crença-conclusão terminal o esteja. Por essa razão, concordamos com a objeção de Ginet de que Klein não capturou o sentido ou a função da tese da dependência no argumento cético-pirrônico do regresso (cf. Infinitism Is Not the Solution to the Regress Problem, p. 148). 
inferencial, temos de ter também uma proposta, nos mesmos moldes, para a justificação doxástica não-doxasticamente inferencial. Ou seja:
$\left(\mathrm{JDNDI}_{\text {inicial }}\right)$ : Se a crença-P de S está inferencialmente, mas não-do- xasticamente justificada, então: (1) o procedimento inferencial gerador da crença-P não é doxástico; (2) o procedimento inferencial executado por $\mathrm{S}$ para crer que P é confiável; (3) o procedimento inferencial que gera a crença-P e a crença-P expressam uma forma adequada de inferência.

Isso posto, retomaremos a nossa discussão em torno de $\left(\mathrm{JDDI}_{\text {inicial }}\right)$. O nosso ponto, agora, é que essa proposta nos permite explicar por que as crenças-alvo do Caso-3 e do Caso-4 estão injustificadas, apesar de terem sido confiavelmente geradas. Comecemos com o Caso-3. Sendo assim, consideremos a suposição, estabelecida pelo próprio caso, de que a crença de S na inconsistência - a crença da qual S partiu para inferir a crença de que chove em Porto Alegre - resultou de outro procedimento de geração de crença de S. Ora, se lembrarmos, em relação ao caso, que o procedimento que gerou a crença naquela inconsistência gera sempre a mesma crença, então esse procedimento não é apenas inconfiável, mas maximamente inconfiável. Se é inconfiável o procedimento que gera a crença de S na inconsistência, então a crença de S na inconsistência está injustificada ${ }^{12}$. E, se a crença de S na inconsistência está injustificada,

${ }^{12}$ Klein defende a tese de que é possível para um agente ter crença justificada em um determinado tipo de inconsistência a qual ele chama de "fraca" (cf. The Virtues of Inconsistency, p. 106). Esse tipo de inconsistência pode ser exemplificado na crença conjuntiva de S de que: Chove e troveja \& (Chove e troveja). Segundo Klein, é esse o tipo de proposição que ocorre na conclusão do chamado "paradoxo do prefácio". A inconsistência da crença de S do Caso-3 seria, por sua vez, aquela que Klein chama de "forte". Mas, afinal, que relevância essa distinção entre inconsistência forte e fraca teria para a análise da justificação da crença? Acreditamos que nenhuma, dado que, se S acredita em uma inconsistência, seja ele forte ou fraca, a crença em questão jamais estará justificada. O nosso argumento em favor desse ponto corre como segue: se o argumento de Klein na defesa da possibilidade da justificação de uma crença em uma inconsistência fraca funciona, então as teses desse argumento de Klein poderiam permitir-nos a conclusão de que justificação e conhecimento são incompatíveis. Isso porque, mesmo que assumíssemos que S pudesse estar justificado na crença de que Chove e troveja \& (Chove e troveja), S jamais poderia saber tal proposição, o que seria contrário ao que Klein pretende na última fase de seu argumento (cf. idem, op. cit., p. 108 e 142). Não é difícil ver que as observações que fizemos a respeito do argumento de Klein atacam o núcleo internalista de sua proposta de justificação doxástica. Mas, é preciso fazer a advertência de que, mesmo que o nosso ataque esteja correto, ele não mostra que a concepção internalista de justificação doxástica estaria, inicialmente, comprometida com a ideia da incompatibilidade entre justificação e conhecimento. Afinal de contas, há propostas internalistas que, contrariando as implicações do 
então não importa o fato de que ela poderia ser, ou converter-se, em um procedimento confiável de geração de crença ao gerar a crença de S de que chove em Porto Alegre. De acordo com (TD), estando injustificada a crença de S na inconsistência, essa crença irá transferir a sua injustificação para o seu produto doxástico, ou seja, a crença de $\mathrm{S}$ de que chove em Porto Alegre. A explicação para a injustificação da crença de que P do Caso-4 não será muito diferente. Afinal de contas, a crença-O daquele caso é a crença de $\mathrm{S}$ de que $\mathrm{S}_{1}$ e $\mathrm{S}_{2}$ são especialistas no assunto-P e que declararam verdades ao se manifestarem sobre ele. Mas, ao fazê-lo, o agente do Caso-4 assumiu um compromisso doxástico com a proposição de que duas proposições contraditórias são verdadeiras. Em outras palavras, o agente assumiu compromisso doxástico com uma falsidade necessária. Ora, se a crença-O do Caso-4 é sobre uma falsidade necessária, então as mesmas conclusões que tiramos a respeito da crença- $\mathrm{Q}$ do Caso-3 valem para ela. Afinal, qualquer procedimento que tivesse gerado a crença de que $\mathrm{Q}$ do Caso-4 seria inconfiável, uma vez que ele produziria apenas aquele tipo de crença. Sendo assim, a crença-O do Caso-4 não está justificada, pois resulta de um procedimento inconfiável e, desse modo, transfere a sua injustificação para a crença de que $\mathrm{P}$ do respectivo caso.

Mas, nesse momento, alguém poderia alegar que o estatuto justificacional das crenças-alvo do Caso-3 e do Caso-4 seria outro, se a crença de $\mathrm{S}$ na inconsistência não tivesse sido gerada por nenhum outro procedimento de geração de crença. Tal alegação, porém, erra o alvo. Isso porque, se as crenças-alvo daqueles casos tivessem sido inferidas a partir de crenças em inconsistências quaisquer, as quais, por sua vez, não tivessem sido geradas por nenhum outro procedimento de geração doxástica, aquelas crenças-alvo permaneceriam invariavelmente injustificadas. Afinal de contas, conforme ( $\left.\mathrm{JDDI}_{\text {inicial }}\right)$, a crença-premissa de um procedimento doxástico-inferencial não seria capaz de justificar a crença-conclusão, se ela mesma já não estivesse justificada por um procedimento outro de geração de crença. Em outras palavras, qualquer crença-alvo que seja inferida de uma crença em uma inconsistência, que,

argumento de Klein, negariam justificação para crenças inconsistentes - se tais propostas são bem-sucedidas nisso, pensamos que não, mas essa é outra história. Uma última observação sobre o argumento de Klein pró-inconsistência fraca versará sobre o que ele chama de "princípios de bloqueio". Os tais princípios de bloqueio seriam os impedimentos teóricos para que S pudesse estar justificado em uma inconsistência "forte" - essa sim inaceitável, segundo Klein. E eles fariam o bloqueio em questão, mas sem impedir que S pudesse estar justificado na crença de uma inconsistência fraca (cf. idem, op. cit., p. 122). O que é interessante, nesse caso, é ver que Klein considera normal a permissão dada por aqueles princípios para se crer em uma inconsistência fraca. Desse modo, Klein prefere crer na normalidade dessa permissão a crer que os princípios de bloqueio deveriam ser sumariamente rejeitados, em razão da conexão existente entre conhecimento e justificação. 
por sua vez, não foi gerada por nenhum outro procedimento de geração de crença de $\mathrm{S}$, está injustificada ${ }^{13}$.

${ }^{13}$ (JDDI inicial $)$ também nos permite lidar com casos como o seguinte:

Caso-5: Suponhamos que, até ontem, $S$ acreditava que $\sim P$ : Não mhá discos voadores. Hoje, no entanto, enquanto faz o seu passeio habitual pelo parque, S vê algo a que atribui ser um disco voador e, apenas por conta disso, vem a crer que P: Há pelo menos um Existem discos voadores.

Conforme podemos ver, o Caso-5 não é um caso de incoerência ou de metaincoerência, mas um caso de mudança de opinião. Dado o caso em jogo, queremos discutir, muito brevemente, a alegação, de verve conservantista, de que a crença- $\sim$ P daquele caso teria uma espécie de preponderância sobre qualquer outro procedimento do agente relativamente à justificação/injustificação da crença-P, independentemente de a crença- $\sim \mathrm{P}$ ser falsa ou de ter sido inconfiavelmente formada. Em outras palavras, a crença- $\sim \mathrm{P}$ de $\mathrm{S}$ teria prioridade justificacional em relação à aquisição de qualquer outra crença acerca do assunto ao qual ela se refere. Desse modo, S não poderia, segundo a alegação conservantista, deixar de usar a crença- $\sim$ P como uma espécie de evidência preferencial para a aquisição de quaisquer outras crenças relativas ao assunto ao qual ela se refere. Temos duas observações contra essa alegação. A primeira é a de que temos dificuldade em ver como S poderia mudar justificadamente de opinião sobre qualquer assunto, se aquela tese fosse verdadeira. A segunda é a de que seria necessário que a crença- $\sim P$ estivesse justificada para que a crença- $\sim P$ tivesse algum tipo de ascendência justificacional sobre a crença-P. Afinal de contas, seria absurdo que a crença- $~ P$ preponderasse em termos justificacionais sobre qualquer outro procedimento de geração doxástica de S, se ela fosse injustificada. Ocorre, porém, que, para que a crença- $\sim$ P estivesse justificada, o justificador não poderia ter sido outra crença, pois, conforme já vimos, crenças não são justificadores, mas transferidores de justificação. Assim, se, para estar justificada, a crença- $\sim P$ depende, ulteriormente, de um justificador que não seja doxástico, a crença- $\sim \mathrm{P}$ não tem qualquer ascendência justificacional sobre a crença-P. A crença- $\sim$ P apresenta ainda uma outra particularidade que consideramos importante e que trataremos brevemente aqui. O ponto envolvendo aquela crença, a qual poderíamos chamar de "crença contingente de inexistência", é o de que a sua justificação não poderia ser realizada por nenhum procedimento perceptual. Afinal de contas, se um agente percebesse, por exemplo, algo a que ele atribui ser um centauro, então a crença para estar justificada seria a de que existe, pelo menos, um centauro e não a crença de que não existe nenhum (mais à frente, daremos explicações adicionais sobre alguns dos principais pontos envolvidos nessa discussão). Que procedimento, ou sequência deles, seria capaz de justificar crenças contingentes de inexistência, já que procedimentos perceptuais não o podem? Ora, tendo em vista as implicações que essa pergunta tem para as várias teses defendidas aqui, seria importante prover uma resposta final para ela. Mas, não iremos fazer isso. Nós nos contentaremos apenas em lançar uma hipótese que pensamos possa dar-nos, pelo menos, uma base para obter a resposta desejada. Estamos pensando, mais especificamente, na seguinte sequência: suponhamos que S esteja perceptualmente justificado na crença, por exemplo, de que $\mathrm{x}_{1}$ é um cavalo. Suponhamos também que $\mathrm{S}$ creia justificadamente que, se x é um cavalo, então x não é um centauro. Isso posto, suponhamos que, através de $\mathrm{n}$-procedimentos perceptuais, $\mathrm{S}$ forme as crenças justificadas de que $\mathrm{x}_{2}$ é um cavalo, de que $\mathrm{x}_{3}$ é um cavalo... de que $\mathrm{x}_{\mathrm{n}}$ é um cavalo. Suponhamos agora que, após formar tais crenças, $\mathrm{S}$ lembre dos conteúdos correlativos a essas crenças e, dadas as devidas atribuições, forme a crença conjuntiva de que: $\mathrm{x}_{1}$ é um cavalo, de que $\mathrm{x}_{2}$ é um cavalo... de que $\mathrm{x}_{\mathrm{n}}$ é um cavalo. Isso posto, suponhamos que $\mathrm{S}$ lembre dos conteúdos correlatos a essa crença conjuntiva e do conteúdo correlato a sua crença de que, se $\mathrm{x}$ é um cavalo, $\mathrm{x}$ não é um centauro. Nesse caso, parece-nos que $\mathrm{S}$ teria a possibilidade de crer, inclusive, justificadamente que: $\mathrm{x}_{1}$ não é um centauro, $\mathrm{x}_{2}$ não é um centauro... $\mathrm{x}_{\mathrm{n}}$ não é um centauro. Assumindo agora que " $n$ " é um número indutivamente adequado à situação em jogo, S poderia, por fim, inferir justificadamente a crença de que não existem centauros. 
Vimos acima que (JDDI inicial $)$ fixa a exigência de que a crença-premissa esteja justificada para que a crença-conclusão o esteja. Isso implica, conforme já dissemos, que procedimentos inferenciais de geração de crença não são estritamente justificadores, mas meros transferidores da justificação. Assim, se a crença-conclusão de uma determinada inferência está justificada, a sua respectiva crença-premissa tem de ter sido gerada por um outro procedimento de geração de crença. O procedimento gerador dessa crença-premissa é, por sua vez, inferencial ou não-inferencial. Se ele é inferencial, ele ainda pode ser doxasticamente inferencial ou não-doxasticamente inferencial. Ora, todas essas possibilidades de geração doxástica podem ser representadas mais esquematicamente do seguinte modo:

(FNI): $\quad$ Esquema de geração não-inferencial da crença-premissa:

(1) S executa $\pi$, que é um procedimento não-inferencial de geração de crença, e em resultado forma a crença-A;

(2) S infere a crença-P a partir da crença-A.

(FNDI): $\quad$ Esquema de geração não-doxasticamente inferencial da crença-premissa:

(1) S executa $\pi$, que é um procedimento não-doxasticamente inferencial de geração de crença, e em resultado forma a crença-B;

(2) S infere a crença-P a partir da crença-B.

(FDI): $\quad$ Esquema de geração doxasticamente inferencial da crença-premissa:

(1) S infere a crença-O a partir da crença- $\mathrm{R}^{14}$;

(2) S infere a crença-P a partir da crença-Q.

${ }^{14}$ É importante notar que, se tivéssemos usado o mesmo modelo de frase dos esquemas anteriores, a linha (1) de (FDI) seria "S executa $\pi$, que é um procedimento doxasticamente inferencial de geração de crença, e em resultado forma a crença-R". Mudamos o padrão tendo em vista os seguintes objetivos: tornar claro que a crença-R de S é o procedimento causador da crença para o tipo de geração doxástica que denominamos "inferência"; tornar claro que a proposição-R entra na caracterização do procedimento que causa a crença- $R$ de S. Isso contraria algumas das teses de Goldman no que tange ao tratamento dado por ele ao problema da generalidade (cf. What is Justified Belief, p. 182). A restrição que Goldman faz contra o uso do conteúdo proposicional na identificação de um procedimento de geração da crença é algo que consideramos equivocado. Afinal de contas, se desconsiderássemos o conteúdo proposicional, como poderíamos distinguir o procedimento de geração de crença expresso na linha (1) de (FDI) do procedimento de geração de 
Ora, a crença-P da linha (2) de (FDI) pode estar justificada apenas se a respectiva crença-premissa - a crença- $\mathrm{Q}$ - também o estiver. E, para que a crença- $\mathrm{Q}$ esteja justificada, ela tem de ter sido causada por outro procedimento de geração de crença de S. Considerando que o procedimento em questão é doxasticamente inferencial, a exigência estabelecida em (TD) vale também para a crença-premissa lá correspondente, ou seja, a crença-R. Vemos, então, que a exigência expressa em (TD) não se aplica apenas à inferência terminal de uma cadeia de inferências doxásticas, mas a todas as inferências que a ela pertencem. Nesse caso, para que a crença terminal de uma cadeia de inferências esteja justificada, é necessário que todas as crenças-premissas presentes na cadeia também estejam. Sendo assim, podemos concluir que, se $\mathrm{S}$ dispusesse apenas de procedimentos doxásticos de geração de crença, ele jamais teria uma crença justificada. Isso implica, por sua vez, que, para S estar justificado na crença-conclusão terminal de uma sequência de inferências, é necessário que a primeira crença-premissa daquela sequência resulte de um procedimento não-doxástico de geração de crença de $\mathbf{S}^{15}$. Em outras

crença expresso na linha (2) de (FDI)? Além do mais, conforme já apontamos in: $O$ Confiabilismo de A. I. Goldman e o Problema da Generalidade, o uso do conteúdo proposicional na caracterização do procedimento de geração da crença não acarreta a sucumbência da concepção confiabilista diante das objeções da indistinguibilidade e da singularidade.

15 Essa afirmação é parte do pacote de um tipo de proposta fundacionista que poderíamos chamar de "não-doxasticista" e que apresenta inúmeras vantagens sobre a concorrência no tratamento que dispensa ao problema da infraestrutura da justificação. Uma delas é a de barrar a conclusão paradoxal de, pelo menos, uma versão do argumento cético do regresso da justificação. Isso porque essa conclusão cética depende da verdade da tese de que apenas procedimentos doxásticos de geração de crença seriam capazes de produzir crença justificada. Ao postular que só procedimentos não-doxásticos de geração de crença poderiam ser justificadores doxásticos, o fundacionismo não-doxasticista bloqueia a conclusão paradoxal do argumento cético em questão. Sobre as diferentes versões do argumento do regresso, diríamos que podemos encontrar, pelo menos, duas delas na literatura. $\mathrm{Na}$ versão que consideramos fazer parte do argumento cético-pirrônico, o argumento do regresso assume a tese de que, para um agente ter crença justificada de que $\mathrm{P}$, esse agente tem de revisar reflexivamente a sua crença de que $P$, fazendo-o exclusivamente através da oferta de razões (ou seja, crenças) que sejam adequadas à verdade da proposição-P e que, nesse oferta de razões, o agente considere todas as evidências e contraevidências das quais dispõe, tanto para a verdade da proposição-P, quanto para a confiabilidade do procedimento através do qual ele formou a crença. Se o agente fosse bem-sucedido nessa empreitada, ele não apenas estaria justificado na crença original de que $\mathrm{P}$, bem como estaria justificado na ratificação dessa crença. Já a segunda versão do argumento do regresso, simplesmente, não assume a necessidade daquela oferta de razões para que o agente tenha crença justificada de que P, esteja o agente em um ambiente de revisão doxástica ou não. Essa última versão é aquela a que nos referimos no início dessa nota e para a qual acreditamos que a proposta fundacionista não-doxasticista possa dar uma resposta definitiva. Isso porque, ao negar que uma crença-premissa possa constituir o justificador de uma crença-conclusão, o 
palavras, para que S esteja justificado na crença-conclusão terminal de uma sequência de inferências, é necessário que a primeira crença-premissa daquela sequência resulte, ou de um procedimento não-inferencial, e, nesse caso, a geração da crença-premissa seria expressa por um esquema como (FNI), ou de um procedimento não-doxasticamente inferencial, e, nesse caso, a geração da crença-premissa seria expressa por um esquema como (FNDI).

fundacionismo não-doxasticista pode inverter a estratégia de redução ao absurdo da justificação, que o cético pretenderia fazer com o uso do argumento do regresso. Ou seja, podemos argumentar que o argumento cético do regresso pode ser devidamente transformado em uma redução ao absurdo da tese de que uma crença-premissa possa ser o justificador de uma crença-conclusão. Depois de fazê-lo, acabaríamos nos deparando com um dilema em relação ao qual, ou teríamos de negar a tese de que uma crença-premissa pudesse ser o justificador de uma crença-conclusão, ou teríamos de assumir que a justificação doxástica seria algo impossível de ser obtido. Considerando que a impossibilidade de alguém estar justificado em pelo menos uma proposição é algo contraintuitivo, poderíamos concluir pela falsidade da tese de que uma crença-premissa possa ser o justificador de uma crença-conclusão. Ora, se tal conclusão é adequada, e pensamos que o seja, então ela não apenas produz forte impacto nas respostas concorrentes - coerentismo e infinitismo -, no que tange ao tratamento dessa segunda versão do argumento cético do regresso, como também atinge as respostas irmãs, como o fundacionismo da crença básica autojustificada e o fundacionismo da crença básica que não demanda justificação (cf., por exemplo, o fundacionismo doxasticista de segunda ordem de BonJour in: Epistemic Justification: Internalism vs. Externalism, Foundations vs. Virtues e o fundacionismo da evidência direta de estados subjetivos auto-apresentantes proposto por Chisholm in: Teoria do Conhecimento). Uma última questão envolvendo o fundacionista não-doxasticista é sobre se propostas desse tipo têm, obrigatoriamente, de ser expressas por meio de definições recursivas. É tão comum representar propostas fundacionistas através de definições recursivas que poderíamos ser induzidos à crença de que fazer isso é inevitável (por exemplo, Goldman faz uso desse recurso in: What is Justified Belief?, p. 183 e Dretske in: Conclusive Reasons, p. 10-11). Contudo, parece-nos que o uso de definições recursivas só seria inevitável, se não pudéssemos analisar o conceito de justificação inferencial separadamente do conceito de justificação não-inferencial ou do conceito de justificação não-doxasticamente inferencial. Mas, acreditamos que não apenas podemos fazê-lo como é necessário que o façamos. O fato de que a justificação de uma crença-conclusão depende da justificação de todas as crenças-premissas de uma sequência de inferências não mostra que a análise do conceito de justificação doxástica tenha de ser expressa recursivamente. O que isso nos mostra, em rigor, é que a justificação doxástica inferencial difere relevantemente da justificação não-inferencial e que ambas diferem relevantemente da justificação não-doxasticamente inferencial. E, se estamos lidando com tipos diferentes de justificação, estamos lidando com diferentes conceitos. Claro, isso não mostra que definições recursivas não poderiam ser usadas para exprimir a análise da justificação doxástica, mas é suficiente para provar o ponto de que não é necessário fazermos uso desse recurso linguístico para atingirmos as nossas metas de análise conceitual. Para sermos ainda mais honestos, nós não acreditamos, justamente em razão da natureza da análise conceitual, que poderíamos usar definições recursivas para expressar adequadamente os resultados desse tipo de atividade intelectual. Esse, porém, não é o espaço adequado para discutirmos esse ponto mais do que já fizemos. 
A conclusão extraída no final da primeira seção enfrenta, porém, algumas objeções. A primeira surge a partir de considerações que envolvem a natureza e a aplicação do método hipotético-dedutivo. Essa objeção argumenta que, se um usuário desse método confirma a sua hipótese de partida através do teste observacional e, em função disso, forma a crença na proposição-objeto da hipótese, o método poderia constituir-se no justificador da respectiva crença ${ }^{16}$. Segue a objeção argumentando que a geração de uma crença através da execução do método hipotético-dedutivo resultaria, assim, da combinação de um procedimento não-doxasticamente inferencial (que ocorreria na fase da formulação da hipótese) com um procedimento não-inferencial (que ocorreria na fase do teste observacional). A objeção conclui que o esquema correto de representação da geração de uma crença que resulta do uso do método hipotético-dedutivo combina os esquemas (FNI) e (FNDI) o que contraria o que afirmamos anteriormente a respeito da geração doxástica e de seus respectivos esquemas de representação. Além disso, se um esquema híbrido fosse representacionalmente necessário, tal como a objeção acima o estabelece, nós também teríamos que ceder diante da alegação da necessidade do uso de definições recursivas na representação da análise conceitual.

Talvez não consigamos dar aqui uma resposta plenamente satisfatória à objeção acima. Estamos convencidos, porém, de que as observações que se seguem permitirão ao menos o encaminhamento da resposta pretendida. Começaremos com o que nos parece consistir o núcleo crítico da primeira objeção, ou seja, a pressão pelo fato de termos considerado o método hipotético-dedutivo como sendo incapaz de justificar uma crença. De fato, consideramos que o método hipotético-dedutivo não pode constituir-se em um justificador doxástico. Senão, vejamos: a objeção acima assumiu algo que, a nosso ver, é correto acerca da natureza dos métodos, que é o fato de assumir que o método hipotético-dedutivo é constituído por uma sequência de procedimentos. A objeção assumiu também que, ao final da execução da rotina correspondente, o método geraria uma crença justificada. Ora, fato é que, embora a objeção acima contenha algumas verdades, ela carrega ao menos uma falsidade. Isso porque é falsa a tese de que o método hipotético-dedutivo é o gerador da crença. Afinal de contas, mesmo que, ao final da rotina de procedimentos

${ }_{16}$ Karl Popper defende, ou pelo menos sugere, a tese de que o método hipotético-dedutivo não começa nem termina com uma crença (cf. The Logic of Scientific Discovery e Conhecimento Objetivo). Cf. no Apêndice uma breve discussão sobre o tema. 
que constitui o método em discussão, resultasse uma crença, não teria sido o método hipotético-dedutivo o causador, mas, simplesmente, o último procedimento que o constitui, ou seja, o procedimento perceptual, que é relativo ao chamado "teste observacional". Ora, o justificador de uma crença tem de ser o seu causador. Desse modo, se, ao final da sequência de procedimentos que constitui o método hipotético-dedutivo, uma crença justificada fosse gerada, ela certamente não teria sido o resultado causal do método hipotético-dedutivo, mas do último procedimento da sequência que o constitui. Ora, e se agora considerarmos que o último procedimento daquela sequência não resulta de qualquer hibridação de diferentes tipos de procedimento de geração de crença, podemos concluir que o emprego do método hipotético-dedutivo não fornece nenhum argumento a favor daquela objeção. Mantém-se, assim, firme a tese de que, se uma crença-premissa está justificada, ela resulta ou de um procedimento não-inferencial, e nesse caso a geração da crença-premissa seria expressa por um esquema como (FNI), ou de um procedimento não-doxasticamente inferencial, e nesse caso a geração da crença-premissa seria expressa por um esquema como (FNDI).

A segunda objeção contra a tese aqui defendida, de que a geração de uma crença-premissa justificada ocorreria ou através da execução de um procedimento não-inferencial ou através da execução de um procedimento não-doxasticamente inferencial, faz considerações em torno da chamada "objeção da galinha com pintas"17. Inspirada nessa última, a segunda objeção argumenta, em razão de uma alegada diferença de conteúdo, ou informação, entre procedimentos perceptuais e crenças relativas ao mundo exterior, que tais procedimentos não seriam capazes de justificar crenças relativas ao mundo exterior. Essa segunda objeção acrescenta também que crenças acerca do mundo exterior não poderiam ser justificadas por meio de procedimentos não-doxasticamente inferenciais, pois esses procedimentos seriam capazes de justificar apenas crenças em tautologias. Essa objeção conclui que, se a tese que estamos defendendo fosse verdadeira, a justificação de crenças-premissa relativas ao mundo externo não seria possível, o que constituiria, é claro, um absurdo, caso fosse verdadeiro.

O que dizer da objeção acima? Em primeiro lugar, concederemos que procedimentos não-doxasticamente inferenciais seriam capazes de justificar tão só crenças em tautologias. Temos sugerido que isso seja assim e continuaremos a fazê-lo no decorrer do ensaio (as razões para

17 Para ver um uso antifundacionista da "objeção da galinha com pintas (pintada?)", cf. Sosa, em especial o Capítulo 7, in: Epistemic Justification: Internalism vs. Externalism, Foundations vs. Virtues. Cf. também uma resposta fundacionista sumária contra essa objeção in: Chisholm, Theory of Knowledge, $3^{\mathrm{a}}$ ed., p. 25. 
sustentar esse ponto, e pontos afins, começarão a ser expressas a partir da discussão do Caso-6 e do Caso-7). Em segundo lugar, e por razões também ligadas a essa concessão inicial, aceitamos a objeção de que um determinado tipo de déficit de conteúdo/informação entre o procedimento de geração de crença e a crença gerada impediria a sua justificação (as razões para sustentar esse ponto também começarão a ser dadas a partir da discussão do Caso-6 e do Caso-7). Mas, há pontos que não queremos conceder à objeção em questão. Por exemplo, não nos parece haver um argumento correto para sustentar a tese de que procedimentos perceptuais estariam sempre fadados a apresentar alguma diferença relevante na quantidade de conteúdos/informaçõesão quando,comparados às crenças causadas por aqueles procedimentos. O ponto é que, se procedimentos perceptuais podem causar crenças cujo conteúdo/informação veiculado naqueles procedimentos seja relevantemente repetido na crença que eles causam - e eles podem fazê-lo -, os procedimentos perceptuais não estariam - dadas as razões invocadas na segunda objeção - impedidos de justificar as crenças que causam ${ }^{18}$.

\section{III}

Nessa seção, queremos ampliar a nossa discussão a respeito da validade formal entre procedimentos de geração de crença e a crença por eles gerada. Tentaremos mostrar que essa exigência também se aplica a casos de geração doxástica não-inferencial. Para vê-lo, acompanhemos o que segue:

Caso-6: Suponhamos que, em t, S vê algo a que atribui ser um gato e, somente em função disso, vem a crer que Q: existe pelo menos um cão. Já, em t', S vê algo a que atribui ser um cão, mas, nesse caso, o procedimento lhe causa a crença de que P: há pelo menos um gato.

Caso-7: Suponhamos que, durante o seu passeio matinal, S vê algo a que atribuiu ser um gato e, somente em função disso, vem a crer

18 Outra objeção, ainda contra a tese de que procedimentos perceptuais seriam capazes de justificar crenças, não apela para uma suposta diferença sistemática de conteúdo entre procedimentos perceptuais e crenças, mas para uma diferença supostamente irremediável na natureza atributiva de procedimentos perceptuais e crenças. Essa objeção argumenta que, ao contrário das crenças, os procedimentos perceptuais não envolvem atribuição conceitual e, por essa razão, não podem justificá-las. Não temos a pretensão de conduzir uma discussão mais ampla a respeito desse assunto aqui. 
que P: há pelo menos um gato. Suponhamos agora que, durante um passeio vespertino, $\mathrm{S}$ vê algo a que atribui ser um gato e, somente em função disso, vem a crer que $\sim P$.

Ora, atribuímos injustificação a ambas as crenças-alvo dos casos acima. Por que, de um ponto de vista puramente atributivo, nós fazemos isso? Alguém poderia arriscar a resposta de que, ao entrarmos em contato com os respectivos casos, presumimos que os procedimentos usados pelos respectivos agentes não eram confiáveis ${ }^{19}$ ou presumimos, simplesmente, que o agente não satisfizera alguma outra exigência relevante para a justificação doxástica ${ }^{20}$. Mas, embora tivéssemos feito tais presunções em relação aos casos em jogo, elas não teriam importância aqui. Afinal de contas, mesmo que incorporemos a suposição de que os respectivos procedimentos de geração de crença sejam confiáveis - inclusive o procedimento de geração da crença-alvo do Caso- $7^{21}$ - e a suposição de

19 De fato, podemos atribuir conceitos aos itens de uma hipótese sem que as suposições que a constituem veiculem aqueles conceitos. Nesse caso, poderíamos eventualmente dificultar, e até impedir, o uso daquela hipótese como exemplo ou contraexemplo para alguma proposta de análise. Para vê-lo, suponhamos que o conjunto completo de conceitos que são necessários para que algo seja um $\mathrm{F}$ seja composto pelos conceitos G, H e I. Suponhamos que uma determinada hipótese veicule as suposições de que $\mathrm{x}$ é G e H, porém, omita a suposição acerca de se x seria, ou não, um I. Em uma situação assim, poderíamos completar a história deixada em aberto pela hipótese atribuindo o conceito-I àquele item. Tais atribuições, que gostaríamos de chamar aqui de "atribuições presumidas", poderiam explicar algumas situações de divergência atributiva. Por exemplo, se a hipótese fosse omissa na declaração de algum dos predicados G, H ou I, diferentes atribuidores poderiam divergir na atribuição do conceito-F, não porque usam conceitos diferentes sob a mesma nomenclatura, mas porque a hipótese foi omissa em expressar uma sentença cujo predicado seria um dos componentes do conceito em jogo. Nesse caso, os agentes poderiam fazer atribuições presumidas divergentes, ou seja, enquanto um dos agentes atribuiria, por exemplo, o conceito-I, o outro agente não o faria. É claro, porém, que nem toda divergência atributiva pode ser explicada com um recurso a tais atribuições presumidas.

20 Uma das exigências que consideramos relevante para a justificação doxástica, mas cuja satisfação não é expressa explícita ou implicitamente nos casos acima, é a de que $\mathrm{S}$ detenha a meta de gerar mais crenças verdadeiras do que falsas. Aliás, é importante registrar que o que converte um mero procedimento de geração de crença em um modo de geração de crença se trata justamente do fato de $\mathrm{S}$ deter a meta de gerar mais crenças verdadeiras do que falsas.

${ }^{21}$ Os casos em discussão oportunizam uma interessante observação sobre a relação entre o conceito de confiabilidade e a capacidade de um procedimento de geração de crença se constituir em um justificador doxástico. É o seguinte: para que um procedimento de geração de crença seja confiável, ele tem de causar mais crenças verdadeiras do que falsas. Não se segue disso, entretanto, que, para ser confiável, um procedimento tenha de causar sempre a mesma crença (cf. à frente uma discussão adicional a respeito desse ponto). Por essa razão é que dissemos acima que o procedimento de $\mathrm{S}$ no Caso-7 poderia ser confiável. Para tanto, bastaria que, dentre as crenças de $\mathrm{S}$ daquele caso, o procedimento em questão gerasse mais vezes a crença verdadeira, 
satisfação de outras exigências feitas até aqui em justificação doxástica, continuaremos atribuindo injustificação àquelas crenças-alvo. Nesse caso, a pergunta relevante passa a ser a seguinte: que conceito(s) atribuímos aos procedimentos de $\mathrm{S}$ de modo que, em ambos os casos, essa atribuição impede que eles sejam justificadores daquelas crenças-alvo? A nossa resposta é a de que pelo menos um dos conceitos que satisfazem a essa pergunta tem relação com a inadequação formal na geração das crenças dos agentes dos casos em discussão. Mais esquematicamente, queremos propor a seguinte análise parcial, e inicial, para a justificação doxástica não-inferencial:

(JDNI inicial $):$ Se a crença-P de S está não-inferencialmente justificada, então (1) o procedimento- $\pi$ através do qual $S$ forma a crença-P é um procedimento não-inferencial de geração de crença; (2) $\pi$ é confiável; (3) a combinação de $\pi$ com a crença-P é formalmente adequada.

Com $\left(\mathrm{JDNI}_{\text {inicial }}\right)$ em mãos, a pergunta analiticamente relevante passa a ser a pergunta acerca do que é uma combinação formalmente adequada entre um procedimento de geração de crença e a crença por ele causada. Para respondê-la, vamos começar supondo que S vê algo a que atribui ser um F. Ora, dado o procedimento perceptual em questão, que crença diríamos que seria formalmente adequada para S?

do que a crença falsa. Assim, chamaremos de "isodoxástico" o procedimento que no mundo em que ocorre, causa sempre a mesma crença e de "heterodoxástico" o procedimento que, no mundo em que ocorre, causa crenças diferentes. Sendo assim, vemos que procedimentos heterodoxásticos podem apresentar uma propriedade que poderíamos chamar de "confiabilidade temática". Como a própria expressão já sugere, a confiabilidade temática tem a ver com o tema/assunto da proposição que é objeto da crença gerada pelo procedimento. Para entendermos melhor, acompanhemos as seguintes considerações: suponhamos que $\pi$ e $\pi_{1}$ são procedimentos de geração de crença, os quais, além de serem inconfiáveis, compartilham o mesmo grau de inconfiabilidade, isto é, eles não apenas geram mais crenças falsas do que verdadeiras, mas o fazem à mesma taxa. Suponhamos também que $\mathrm{P}$ e $\mathrm{Q}$ representam princípios naturais do mundo em que $\pi$ e $\pi_{1}$ são executados e que, enquanto $\pi$ gera ou a crença de que $\sim \mathrm{P}$ ou a crença de que $\mathrm{Q}$ (gerando, porém, mais vezes a crença de que $\sim \mathrm{P}$, que é falsa), $\pi_{1}$ gera ou a crença de que $\mathrm{P}$ ou a crença de que $\sim \mathrm{Q}$ (gerando, porém, mais vezes - e na mesma medida que $\pi$ gera a crença de que $\sim P-$ a crença $\sim Q$, que é falsa). Nesse caso, vemos que, embora $\pi$ e $\pi_{1}$ sejam ambos inconfiáveis, quanto à geração de crença verdadeira, eles seriam tematicamente confiáveis. Isso porque $\pi$ geraria mais vezes a crença na proposição- $Q$, que é verdadeira, do que $\pi_{1}$ geraria a crença na proposição- $\sim \mathrm{Q}$, e $\pi_{1}$ geraria mais vezes a crença na proposição-P, que é verdadeira, do que $\pi$ geraria a crença na proposição- $\sim$ P. Ou seja, $\pi$ seria tematicamente confiável em relação à proposição- $\mathrm{Q}$, enquanto $\pi_{1}$ seria tematicamente confiável em relação à proposição-P. 
Diríamos que seria a crença cuja proposição-objeto fosse a crença de que algo fosse um $\mathrm{F}$. E, sendo assim, negaríamos que seria formalmente adequada, por exemplo, a crença de $\mathrm{S}$ de que algo fosse um $\mathrm{G}^{22}$. Em outras palavras, o que estamos exigindo para a justificação de crenças não-inferencialmente formadas é que elas resultem de um procedimento de geração de crença que tenha atribuído estritamente o mesmo conceito que figura na proposição-objeto da crença-alvo. Mais esquematicamente, estamos propondo o seguinte para o conceito de combinação formalmente adequada entre um procedimento não-inferencial de geração doxástica e a crença que ele gera:

(CNIFA): Se a combinação do procedimento não-inferencial $\pi \mathrm{com}$ a crença de $S$ de que $x$ é um $F$ é formalmente adequada, então $\mathrm{S}$ atribuiu o conceito-F a x na execução de $\pi$.

(CNIFA) nos permite, em princípio, lidar com os seguintes casos de injustificação doxástica:

Caso-8: Suponhamos que, enquanto passeia despreocupadamente pela rua, $\mathrm{S}$ ouve um transeunte qualquer, $\mathrm{S}_{1}$, declarar que $\mathrm{P}$ : há pelo menos um gato. Suponhamos, então, que, somente por conta de sua audição da declaração de $\mathrm{S}_{1}$, $\mathrm{S}$ forma a crença de que P. Para encerrar, suponhamos que $\mathrm{S}_{1}$ seja fonte confiável de informação em relação ao assunto da proposição- $\mathrm{P}^{23}$

${ }^{22}$ Isso permaneceria verdadeiro, mesmo que a relação entre ser um $\mathrm{F}$ e ser um $\mathrm{G}$ fosse analiticamente verdadeira. Por exemplo, suponhamos que S visse algo a que atribuísse ser um homem. Suponhamos agora que fosse analiticamente verdadeira a afirmação de que, se x é um homem, x é um bípede implume. Ora, embora x ser um homem implicasse $\mathrm{x}$ ser um bípede implume, a crença de $\mathrm{S}$ de que $\mathrm{x}$ fosse um bípede implume não seria formalmente adequada ao seu procedimento de geração de crença, no caso, o fato de ele ter visto algo a que atribuíra ser um homem.

${ }^{23}$ Para lidar com um caso análogo, Goldman assumiu a tese de que o procedimento envolvido na geração testemunhal de uma crença não é um processo de geração de crença, mas um método de geração de crença (cf. Epistemology and Cognition, p. 92-95). Segundo Goldman, um processo é inato ao agente, enquanto um método se trata de um processo adquirido. Se métodos são processos adquiridos, eles poderiam, segundo Goldman, ser confiavelmente adquiridos ou não. Por essa razão, Goldman fixa a exigência de que, para justificar uma crença, um método, além de ser confiável, tem de ter sido adquirido por um processo confiável de aquisição de processos (cf. a discussão de Goldman do caso Humperdink-Fraud, in: Epistemology and Cognition, p. 91-92, e do caso Dalai Lama, idem, op. cit., p. 109-110, bem como a sua explicação para a diferença entre justificação primária e secundária in: Strong and Weak Justification, p. 51-56). A distinção feita por Goldman, entre procedimentos inatos e adquiridos, corre tranquila para nós. O mesmo acontece com a exigência ligada ao que ele chama de "justificação secundária", a qual seria a justificação de crenças causadas por métodos de geração 
Caso-9: Suponhamos que, enquanto passeia despreocupadamente pela rua, $\mathrm{S}$ ouve um transeunte qualquer, $\mathrm{S}_{1}$, declarar, em $\mathrm{t}$, que $\mathrm{P}$ e que, exclusivamente em função disso, $\mathrm{S}$ forma a crença-P. Em t', também enquanto passeia pela rua, $\mathrm{S}$ ouve outro transeunte, $\mathrm{S}_{2}$, declarar que $\sim \mathrm{P}$ e, apenas em função disso, suporemos, $\mathrm{S}$ forma a crença- P. Em t", $\mathrm{S}$ lembra da declaração de que $\mathrm{P}$ por $\mathrm{S}_{1} \mathrm{e}$ da declaração de que $\sim P$ por $S_{2}$ e, exclusivamente em função disso, forma a crença de que P. Suponhamos que, assim como no caso anterior, $\mathrm{S}_{1}$ é fonte confiável de informação em relação ao assunto da proposição- $\mathrm{P}^{24}$.

Ora, o ponto que mais queremos destacar em relação aos casos acima é o de que, independentemente dos procedimentos lá executados serem confiáveis, as suas crenças-alvo estão injustificadas. Isso acontece porque as crenças-alvo em questão não são formalmente adequadas aos procedimentos que as geram. É claro que as coisas teriam sido diferentes, se, no Caso-8, em vez de $\mathrm{S}$ ter acreditado que $\mathrm{P}$, ele tivesse acreditado que $\mathrm{S}_{1}$ declarara que $\mathrm{P}$. Nesse caso, ele teria formado uma crença formalmente adequada ao respectivo procedimento de geração doxástica, uma vez que somente essa crença manteria a correlação formal exigida por (CNIFA). Do mesmo modo, se, no Caso-9, em vez de $\mathrm{S}$ ter acreditado que $\mathrm{P}$, ele tivesse acreditado que $\mathrm{S}_{1}$ declarou que $\mathrm{P}$ e $\mathrm{S}_{2}$ declarou que $\sim \mathrm{P}, \mathrm{S}$ teria uma crença cuja exigência de adequação formal entre ela e seu procedimento gerador teria sido satisfeita.

de crença, em vez de processos de geração de crença. Temos, entretanto, alguma dificuldade em aceitar o tratamento dispensado por Goldman aos casos de geração doxástica testemunhal. Mais precisamente, é difícil aceitar a tese de Goldman de que a geração doxástica testemunhal está ligada a um método de geração de crença, ou seja, a um processo que foi adquirido pelo agente. Não temos a pretensão de discutir essa questão mais detalhadamente aqui. Contudo, acreditamos que é adequado declarar nossa suspeita de que a explicação de Goldman não funciona. Não temos dúvida de que o testemunho de alguém poderia fornecer informações que dariam aos agentes a condição de gerarem crenças que, de outro modo, esses agentes não gerariam. Mas, isso nos parece estar longe da ideia de que os agentes estariam "adquirindo" um procedimento que antes eles não possuíam. O que nos parece é que, em vez de "adquirirem" um procedimento, os agentes simplesmente adquirem informações acerca de qual procedimento, ou sequência de procedimentos, eles deveriam adotar para alcançarem as suas metas.

${ }^{24}$ É importante atentarmos para o fato de que, embora $\mathrm{S}_{1}$ ou $\mathrm{S}_{2}$ tenha declarado uma falsidade, eles poderiam, ainda assim, ser confiáveis declaradores de verdades. Afinal de contas, dada a história completa de suas declarações, eles ainda poderiam ser mais declaradores de verdades do que falsidades. Porém, mais importante do que isso é o fato de que os procedimentos de geração de crença, vinculados à audição das declarações de $\mathrm{S}_{1}$ e de $\mathrm{S}_{2}$, não poderiam ser ambos confiáveis, caso repetissem, na mesma medida, a crença-alvo em questão (mais à frente, veremos que alguma exigência ligada à repetição da crença-alvo é essencial à justificação doxástica). 
Mas, a exigência de adequação formal feita aqui exige algum esclarecimento quando a aplicamos a casos de geração doxástica testemunhal. Para vermos o porquê, começaremos com a suposição de que $\mathrm{S}$ ouve $\mathrm{S}_{1}$ dizer "P". Nesse caso, haveria duas possibilidades: a de que S tenha entendido a manifestação verbal " $\mathrm{P}$ " de $\mathrm{S}_{1}$ ou, então, a de que ele não a tenha entendido. Isso posto, teríamos duas perguntas: se S não tivesse entendido aquela manifestação, qual crença, segundo $\left(\mathrm{JDNI}_{\text {inicial }}\right)$, seria formalmente adequada ao procedimento de geração de crença em jogo? $\mathrm{E}$, se ele a tivesse entendido, qual seria a crença? Respondendo a essas perguntas, parece-nos que, para o caso de $\mathrm{S}$ não ter entendido aquela manifestação, a crença formalmente adequada, segundo $\left(\mathrm{JDNI}_{\text {inicial }}\right.$ ), seria a crença de $\mathrm{S}$ de que $\mathrm{S}_{1}$ dissera "P". Já para o caso da manifestação de $\mathrm{S}_{1}$ ter sido inteligível para $\mathrm{S}$, a crença formalmente adequada, segundo ( $\mathrm{JDNI}_{\text {inicial }}$ ), não seria a crença de $\mathrm{S}$ de que $P$, tal como alguém poderia inicialmente pensar, mas a crença de que $\mathrm{S}_{1}$ dissera que $\mathrm{P}$. Ou seja, de acordo com $\left(\mathrm{JDNI}_{\text {inicial }}\right)$, S não poderia formar justificadamente a crença de que $\mathrm{P}$, se o procedimento de geração de $\mathrm{S}$ fosse o fato dele ter ouvido $\mathrm{S}_{1}$ dizer que $\mathrm{P}$.

Mas, sendo assim, temos aqui certa dificuldade em mãos, pois, dado que é perfeitamente possível a um agente crer justificadamente que $\mathrm{P}$ a partir de um testemunho auditivo, tal como o exemplificado há pouco, temos de oferecer alguma explicação sobre como uma crença justificada de que $\mathrm{P}$ seria testemunhalmente viável, considerando a exigência de adequação formal expressa por ( $\left.\mathrm{JDNI}_{\text {inicial }}\right)$. Para fazermos isso, temos de partir da suposição de que $\mathrm{S}$ tenha entendido a manifestação verbal de $\mathrm{S}_{1}$. Nesse caso, e em sintonia com ( $\left.\mathrm{JDNI}_{\text {inicial }}\right)$, S poderia, primeiramente, crer que $\mathrm{S}_{1}$ disse/declarou que $\mathrm{P}$. O próximo passo, para resolvermos a dificuldade em jogo, será fornecermos uma resposta à seguinte pergunta: que conceito $\mathrm{S}$ teria de atribuir $\mathrm{a} \mathrm{S}_{1}$, ou à sua declaração, para que ele pudesse vir a crer que $\mathrm{P}$ em conformidade com $\left(\mathrm{JDNI}_{\text {inicial }}\right)$ ? A nossa resposta recai sobre o conceito de declarador de uma verdade. Ou seja, para que $\mathrm{S}$ forme a crença de que $\mathrm{P}$, de maneira formalmente correta a partir do fato dele ter testemunhado a declaração de que $\mathrm{P}$ por $\mathrm{S}_{1}$, $\mathrm{S}$ teria que atribuir a $\mathrm{S}_{1}$ o conceito de declarador de uma verdade. Nesse caso, a conjunção do conteúdo da crença de $\mathrm{S}$ de que $\mathrm{S}_{1}$ é declarador de uma verdade com o conteúdo da crença de $\mathrm{S}$ de que $\mathrm{S}_{1}$ declara que $\mathrm{P}$ é tal que veicularia os conceitos que permitiriam a $\mathrm{S}$ gerar, via testemunho e, de acordo com as exigências formais de ( $\mathrm{JDNI}_{\text {inicial }}$ ), a crença de que $\mathrm{P}$.

É claro, ainda não explicamos de que maneira $\mathrm{S}$ poderia gerar a crença de que $\mathrm{S}_{1}$ é declarador de uma verdade em conformidade com as exigências formais aqui propostas. Arriscaremos a ideia de que essa explicação poderia ser dada a partir de considerações envolvendo a 
estrutura de geração doxástica que expressaremos abaixo e, em relação a qual, assumiremos as seguintes abreviaturas: "Lsq*" para "S lembra-se de $\mathrm{S}_{1}$ ter declarado que $\mathrm{P}$ e de $\mathrm{S}_{1}$ ser declarador de uma verdade"25, "-" para "causa", "BsQ" para "S crê que: $\mathrm{S}_{1}$ declarou que $\mathrm{P}$ e $\mathrm{S}_{1}$ é declarador de uma verdade" e "BsP" para "S crê que P":

$$
\mathrm{Lsq}^{*}-\mathrm{BsQ}-\mathrm{BsP}^{26}
$$

${ }^{25}$ Dadas as exigências de adequação formal estabelecidas nesse ensaio, é fundamental que digamos que o tipo de procedimento mnemônico, a que nos referimos com expressões do tipo "S lembra-se de tal-e-tal", envolve necessariamente atribuição conceitual por parte do agente. Isso quer dizer que não são os conteúdos representacionais armazenados - conteúdos ditos "mnemônicos" - os responsáveis pela justificação doxástica de qualquer que seja a crença. Isso porque, assim como no caso dos perceptos, é essencial para a justificação doxástica que os conteúdos de memória recebam a devida atribuição conceitual. Em outras palavras, não são os conteúdos armazenados na memória do agente que são capazes de justificar crenças, mas, as atribuições conceituais que o agente realiza sobre tais conteúdos e que, aqui, representamos através da expressão em destaque no início dessa nota.

${ }^{26}$ Cabem aqui algumas observações adicionais sobre a estrutura acima. A primeira é a de que poderíamos tomar "Lsq" para corresponder, alternativamente, à expressão "S lembra-se de $\mathrm{S}_{1}$ ter declarado que $\mathrm{P}$ e de $\mathrm{S}_{1}$ ser um confiável declarador de verdades". Nesse caso, "BsQ" teria de corresponder à crença de $\mathrm{S}$ de que: $\mathrm{S}_{1}$ declarou que $\mathrm{P}_{\text {e }} \mathrm{S}_{1}$ é um confiável declarador de verdades. E, assim, partindo dessa BsQ alternativa, S inferiria indutivamente, e em perfeita conformidade com ( $\left.\mathrm{JDNI}_{\text {inicial }}\right)$, a crença de que P. A segunda é a de que alguém poderia endereçar-nos a objeção de que a estrutura acima está incompleta. O objetor diria, nesse caso, que a justificação de BsQ depende causalmente, e em última instância, de um ou mais procedimentos perceptuais. Argumentaria o objetor que, para que BsQ estivesse justificada, seria necessário que um ou mais procedimentos perceptuais causassem o armazenamento dos conteúdos de memória de $\mathrm{S}$ e, depois, tais conteúdos mnemônicos causassem Lsq* (o objetor conceder-nos-ia que Lsq* envolve a aplicação de conceitos aos conteúdos armazenados na memória da S). Concluída a objeção, temos dois comentários endereçados a ela. O primeiro é o de que quaisquer que sejam os conteúdos armazenados na memória de $\mathrm{S}$, e sobre os quais $\mathrm{S}$ aplica a atribuição conceitual envolvida em Lsq*, não nos parece necessário que eles tenham sido gerados por um ou mais procedimentos perceptuais de $\mathrm{S}$ para que $\mathrm{BsO}$ viesse estar justificada. Para vê-lo, consideremos as seguintes situações: na primeira, que vamos chamar "standard", o agente recupera algum conteúdo de memória que foi gerado pela execução de um ou mais de seus procedimentos perceptuais e atribui àquele item certo conceito. Na segunda situação, os procedimentos perceptuais de S não chegam a gerar os conteúdos armazenados por $\mathrm{S}$, tal como se daria na situação standard. Isso porque, nessa situação, um gênio benigno implantaria, no lugar daqueles que seriam gerados, caso a situação fosse a standard, conteúdos estritamente correspondentes àqueles que seriam armazenados, se a situação fosse a standard. Vemos, nesse caso, que, embora os conteúdos armazenados na memória de $\mathrm{S}$, e sobre os quais ele aplicaria os conceitos pertinentes, não tenham sido gerados por um ou mais de seus procedimentos perceptuais, isso não seria suficiente para impedir a justificação de sua crença de que Q. Mais: essa segunda situação hipotética também mostra que não seria necessário que os procedimentos perceptuais gerassem os conteúdos mnemônicos para que BsQ estivesse justificada, dado que, naquela situação, eles foram gerados pela atividade do gênio benigno. Além disso, a objeção acima também erra ao exigir que os conteúdos mnemônicos de S causem Lsq* para que BsO possa estar justificada. O que é necessário, 
Ora, mas apesar de termos argumentado até aqui pela verdade de $\left(\mathrm{JDNDI}_{\text {inicial }}\right),\left(\mathrm{JDDI}_{\text {inicial }}\right)$ e $\left(\mathrm{JDNI}_{\text {inicial }}\right)$, essas propostas são, tal como as suas designações já o sugerem, incompletas. Isso pode ser mostrado através do seguinte caso:

Caso-10: Suponhamos que S forma, em t e através da execução de $\pi$, a crença justificada de que P. Suponhamos também que, em t', S repete a crença de que $\mathrm{P}$, agora, porém, através da execução de $\chi$. Suponhamos também que, embora confiável e formalmente adequado à crença-P, $\chi$ é tal que não repete nenhuma das crenças que gera e, com exceção da crença gerada nesse caso, $\chi$ gera apenas crenças formalmente inadequadas.

Embora atribuamos justificação à primeira ocorrência da crença-P, atribuímos injustificação à segunda. Mas, por que as nossas atribuições mudaram? Acreditamos que essa mudança esteja relacionada justamente a duas das propriedades de $\chi$ no caso acima, ou seja, não repetir crença nenhuma, sendo, nesse caso, maximamente heterodoxástico e ser formalmente inadequado em todas as demais circunstâncias de sua ocorrência. Ou seja, embora confiável, $\chi$ é o tipo de procedimento que, em razão das propriedades que possui, chamaríamos de "anômalo"27. Tendo

sim, é que o agente faça contato com aqueles conteúdos, algo que, como podemos ver, ocorre justamente quando o agente atribui conceitos àqueles conteúdos. Em conclusão, podemos dizer que, para que BsQ esteja justificada, não é necessário que haja qualquer circuito causal ligando procedimentos perceptuais a conteúdos mnemônicos e esses a procedimentos mnemônicos.

27 Conforme já dissemos antes, para que um procedimento de geração de crença seja confiável não é necessário que ele sempre gere crenças com o mesmo conteúdo. Além disso, um procedimento pode ser confiável sem gerar uma crença formalmente adequada sequer. Mas, nesse ponto, alguém poderia defender a ideia de que o confiabilismo de Goldman já veda a possibilidade de procedimentos de geração de crença com tais propriedades constituírem justificadores doxásticos. O arrazoado desse defensor seria o seguinte: um processo de geração de crença é constituído pela dupla [input e output], onde o input corresponde ao fator interno a $\mathrm{S}$ e o output corresponde à crença-alvo. Se houvesse uma mudança no output da dupla, então teríamos um processo diferente em jogo, não um processo causando uma crença diferente. Concluiria o defensor que, de acordo com o confiabilismo de Goldman, um processo não poderia ser heterodoxástico. A nossa resposta é a de que o defensor da proposta de Goldman erra em sua exegese e, por conta disso, erra na conclusão de que ela não permite que um processo seja heterodoxástico. O erro exegético cometido pelo defensor da proposta de Goldman é, em grande medida, induzido pelo próprio Goldman. Esse autor faz afirmações que, de fato, sugerem que os processos de geração da crença sejam constituídos pela dupla [input e output] - inputs correspondendo aos fatores internos a S, doxásticos ou não, e os outputs correspondendo às crenças-alvo. Mas, Goldman também afirma explicitamente que processos de geração da crença causam a crença-alvo (cf. What is Justified Belief?, p. 181-183 e Reliabilism in: Routledge Encyclopedia of Philosophy). Mas, 
em vista que a condição anômala de $\chi$ mostra que aquelas propostas de análise são insuficientes, alguém poderia propor a adição da exigência de que o procedimento fosse também isodoxástico. Tal exigência é, porém, muito forte. Afinal de contas, bastaria que um procedimento fosse minimamente heterodoxástico - ou seja, que gerasse apenas uma crença diferente em relação a todas as demais -, para que, segundo a exigência em jogo, todas as ocorrências daquela crença fossem injustificadas. $O$ excesso de força dessa exigência também pode ser constatado no caso das inferências. É que, se exigíssemos que os procedimentos doxástico-inferenciais de geração de crença fossem isodoxásticos, o agente não poderia estar justificado no seguinte caso: suponhamos que, em t, e a partir de sua crença na conjunção ( $G \& H)$, S infere a crença-G, mas, em t', ele infere, a partir da mesma crença conjuntiva, a crença-H. Ora, se considerarmos que o procedimento de geração de ambas as crenças-alvo é o mesmo, porém as crenças-alvo resultantes daquelas ocorrências são diferentes, S não poderia estar justificado em nenhuma delas, caso procedimentos inferenciais tivessem de ser isodoxásticos. Mas, esse seria um resultado contraintuitivo ${ }^{28}$. Uma segunda proposta de resolução do problema, uma que seria supostamente mais fraca do que a anterior, admitiria que procedimentos de geração de crença fossem heterodoxásticos para efeito de poderem contar como justificadores doxásticos. O que ela não admitiria é que eles gerassem uma crença formalmente inadequada sequer. Mas, sendo assim, não é difícil ver que essa proposta também é forte demais. Afinal de contas, bastaria que um

tais afirmações de Goldman são potenciais geradores de confusão e de absurdos. Afinal de contas, se tomarmos o processo para ser constituído pela dupla [input e output], onde o output corresponde à crença-alvo, e assumirrmos que o processo é o causador da crença-alvo, teremos de assumir que o processo causa algo que o constitui, e issoo que é absurdo. Teria a proposta de Goldman de se comprometer com tal absurdo? Não necessariamente, pois os seus termos admitem que a entendamos no sentido de que o processo é o fator interno a S cuja operação toma um input cognitivo qualquer para convertê-lo em um output doxástico (cf. What is Justified Belief?, p. 181). Nessa exegese livre da absurdidade que vimos acima, um processo pode causar crenças diferentes, já que a partir dos mesmos inputs ele pode gerar diferentes outputs doxásticos. Ou seja, ao contrário do que pretendia o hipotético defensor do confiabilismo de Goldman, essa proposta não veda a possibilidade de um procedimento de geração de crença ser heterodoxástico. Além do mais, mesmo que resolvêssemos assumir a tese - absurda de que processos/procedimentos de geração de crença seriam constituídos pela dupla [fator interno a $\mathrm{S}=$ input, crença-alvo = output], a fim de vedarmos a possibilidade de eles gerarem crenças com conteúdo diferente, isso seria inútil para vedar outra possibilidade indesejável: a de gerarem crenças formalmente inadequadas.

28 Caso quiséssemos obter uma conclusão análoga, porém para casos de inferência não-doxástica, bastaria efetuarmos as seguintes mudanças no argumento acima: substituir a crença de $S$ de que $(G \& H)$ pela suposição de $S$ de que $(G \& H)$, substituir a primeira crença-conclusão pela crença de $S$ de que $((G \& H) \rightarrow G)$ e, por fim, substituir a segunda crença-conclusão pela crença de $\mathrm{S}$ de que $((\mathrm{G} \& \mathrm{H}) \rightarrow \mathrm{H})$. 
dado procedimento gerasse apenas uma crença formalmente inadequada para que todas as suas demais ocorrências fizessem dele um injustificador doxástico, independentemente de suas outras qualidades. Uma terceira proposta ainda estabeleceria que a confiabilidade fosse medida levando em consideração apenas aquelas situações em que o procedimento fosse formalmente adequado à crença gerada. Mas, não será difícil ver que essa proposta enfrenta ainda mais dificuldade do que as anteriores, pois, por um lado, ela é demasiadamente fraca e, por outro, demasiadamente forte. Ela é demasiadamente fraca porque, se um procedimento gerasse apenas uma crença formalmente adequada, porém verdadeira, isso seria suficiente, de acordo com aquela proposta, para tornar justificadas todas as demais crenças geradas por esse procedimento, a despeito de sua geração de crença falsa ou de crenças formalmente inadequadas. Por outro lado, a proposta em discussão é demasiadamente forte, haja vista que, se um procedimento gerasse apenas uma crença formalmente adequada, mas falsa, isso seria suficiente, de acordo com aquela proposta, para tornar injustificadas as demais crenças geradas por aquele procedimento.

A nossa sugestão para resolver a dificuldade acima é complementar $\left(\mathrm{JDNDI}_{\text {inicial }}\right),\left(\mathrm{JDDI}_{\text {inicial }}\right)$ e $\left(\mathrm{JDNI}_{\text {inicial }}\right)$ com a exigência de que um procedimento de geração de crenças, para ser um justificador doxástico, não seja anômalo, ou seja, que ele não gere mais crenças formalmente inadequadas do que formalmente adequadas. Mais esquematicamente, essa condição de não-anomalia formal pode ser expressa da seguinte maneira:

(CNAF): $\quad$ Se $\pi$ é um procedimento formalmente não-anômalo de geração de crenças, então, dada a história completa de ocorrências de $\pi$ no mundo em que ele ocorre, $\pi$ gera mais crenças formalmente adequadas do que crenças formalmente inadequadas.

Sendo assim, tomando " $\pi$ " para representar um procedimento qualquer de geração de crença, poderemos, através de (CNAF), corrigir (JDNDI ${ }_{\text {inicial }}$ ), $\left(\mathrm{JDDI}_{\text {inicial }}\right)$ e (JDNI inicial $)$ obtendo, assim, as seguintes propostas:

(JDNDI): Se a crença-P de S está inferencialmente, embora nãodoxasticamente, justificada, então: (1) $\pi$ gera a crença-P de $S$, sendo $\pi$ um procedimento não-doxasticamente inferencial de geração de crença; (2) $\pi$ é confiável; (3) $\pi$ e a crença-P expressam uma forma adequada de inferência; (4) $\pi$ é não-anômalo. 
(JDDI): $\quad$ Se a crença-P de S está inferencialmente e doxasticamente justificada, então: (1) $\pi$ gera a crença-P de S, sendo $\pi$ uma crença de S; (2) $\pi$ é confiável; (3) $\pi$ e a crença-P expressam uma forma adequada de inferência; (4) $\pi$ está justificado (5) $\pi$ é não-anômalo.

(JDNI): Se a crença-P de S está não-inferencialmente justificada, então: (1) $\pi$ gera a crença $P$ de $S$, sendo $\pi$ um procedimento não-inferencial de geração de crença; (2) $\pi$ é confiável; (3) a combinação de $\pi$ com a crença-P é formalmente adequada; (4) $\pi$ é não-anômalo.

Vemos, assim, que as propostas acima não vedam a um procedimento a condição de ser heterodoxástico ou a condição de gerar uma, ou até mesmo mais, crenças formalmente inadequadas para poder ser um justificador doxástico. O que elas vedam a um procedimento de geração de crenças é a condição de gerar, ainda que confiavelmente, mais crenças formalmente inadequadas do que adequadas.

(A ser continuado) 